\title{
An Empirical Analysis for Abnormal Returns from Initial Public Offerings (IPOs): evidence of Iranian oil and chemical industries
}

\author{
Mahdi Filsaraei \\ Dept. of Accounting, Islamic Azad University-Bojnourd, Iran \\ Alireza Azarberahman (Corresponding author) \\ Dept. of Accounting, Islamic Azad University-Mashhad, Iran \\ Tel: +98-915-119-1929Ｅ-mail: a_berahman@yahoo.com
}

Jalal Azarberahman

Supreme Audit Curt of Mashhad, Iran

Received: January 15, 2013 Accepted: March 02, 2013 DOI: 10.5296/ijafr.v3i1.3048

\begin{abstract}
Purpose: The core purpose of this paper empirically study of the initial public offerings (IPOs) of companies accepted in oil and chemical industries. The paper attempts to answer the question of is there any abnormal return from IPOs in listed companies in Tehran Stock Exchange (TSE).

Design/methodology/approach: This research is an applied research, and its design is empirical, which is done by the method of post-event (past information). For the purpose of the study the t-statistic, regression and variance analyses are applied to examine the hypotheses. We use in the analyses a sample of 29 newly accepted Iranian oil and chemical companies listed on TSE for the period of 2001 to 2012. This paper has studied abnormal return and three abnormal phenomena have been considered in capital market. These phenomena consist: (1) underpricing or overpricing of the firm's stock, (2) lower or higher stock return of the firms and (3) Particular period in market for stock transactions volume.

Findings: The results support the hypothesis that there is a positive abnormal return to investing in the newly accepted oil and chemical firms for stockholders. It also shown the firm size is the only factor that can affect the stock abnormal return. With considering significance level, investors have to give attention sequentially to other variables such as stock ownership centralization, going public time and stock offering volume.
\end{abstract}

Keywords: Abnormal Return, Initial Public Offerings (IPOs), Stock Offering Volume. 


\section{Introduction}

Changing the consumption pattern has increased the requirement for unnatural substitute goods and consequently "petrochemical industry" has become an important industry in regard to artificial materials and products varieties. This industry was extended in Europe first, and then in the U.S. Investing is justifiable in this industry because of its eminent role in value added of crude oil and gas. High value added and the relative abundance of producing factors are the relative advantages of this industry and oil industry, which both can be found in Iran sufficiently. Furthermore, exporting the petrochemical products can affect and increase the foreign currency incomes (Haqjoo and Geranmayeh, 2006). Apart from mentioned advantages, products of this industry can be used in producing various consumption, intermediate and investment goods and improve the level of employment and investing sources distribution in deprived regions. This industry formed in Iran in 1963. Nowadays, Iran is in charge of producing $12 \%$ of petrochemical productions in Middle East; this number should increase up to $34 \%$ in next twenty years. Chemical industries have extensive variety and its products can be used diversely; from pharmaceutical industry to health, alimentary, tire and textile industries and to moulding. And crude oil, on which about $65 \%$ of petrochemical products depend, is the main material in chemical and petrochemical industries. Considering the importance of investment in this industry, evaluating the stock price in initial public offering (IPO) of the firms separately seems necessary. In developed countries, investing institutes and banks are usually responsible for pricing the stock in firms that intend to sell their stocks publicly. These institutes, which are experienced in stock pricing, determine the stock price on the basis of current conditions in capital market, analyzing the financial positions and available facilities in the country, profitability of the firm and the stock price in similar firms. Mentioned institutes are in charge of selling and public offering of stocks as well as determining the stock price (Jahankhani and Abdollahzadeh, 1993). It should be pointed out that the meaning of "initial public offering of stocks" in Iran differs from its common definition in other countries and there is no "initial public offering of stocks" in Iran; because "initial public offering of stocks" in other countries refers to newly offered stocks, but primary market is not efficient and constitutional in Iran and does not follow proper rules and orders (Abdeh Tabrizi and Demury, 2003). This leads to the fact that people obtain abnormal return by buying the stocks of these firms. Since May 1995, the stock evaluation office discarded offering the stock basic price because of market influence on the stock price in Tehran stock exchange (TSE) and lack of any rational relation between the stock price and the stock return, and decided not to interfere in determining the stock basic price. Since then TSE has offered the EPS only, and has not declared the stock basic price and has granted the determining of stock price to the mechanism of supply and demand and capability of capital market.

Currently, P/E method is applied in most of pricings and stock evaluations. In fact earning per share (EPS) is multiplied by a number that is called the price to earning per share coefficient to determine the stock value. This is a simple formula, although the stock evaluation is a complicated problem. Applying this method means ignoring the variety of effective factors on the stock price and may lead to determining the stock price inappropriately. In other 
countries, this formula is applied cautiously (Yari and Forqandoust Haqiqi, 2002). In this paper, the trend of stock pricing in initial public offering by active firms in oil and chemical industries in TSE is evaluated precisely.

Considering the importance of capital market in every country economy and its role in getting to a desired and optimum economical structure, it is necessary to continuous test and controls the desired market conditions constantly for achieving the mentioned goals. Otherwise, the market inappropriate -and often harmful- activities may lead to bad national and economical consequences. Furthermore, activities of capital market should be tested precisely and incessantly and its probable inappropriate conditions should be distinguished in order to find alternatives to solve them via proper strategies.

Clearly, improving the market activities increases its reliability and consequently more investments would be attracted. Thus we have studied a special aspect of stock exchange activities that can be considered as an effective factor on stock exchange and its desirable efficiency.

Paying attention to this fact that determining the stock price even in countries with advanced capital market encounters many difficulties, pricing should be fulfilled precisely in stock public offering. If the stock price increases after the initial public offering, more people will be encouraged to buy the firm next stocks. On the other hand, if the stock price decreases or does not increase after the initial public offering, people will incur a loss.

\section{Research Literature}

The results of Ibbotson research in 1975 indicated that the return of stock transactions in secondary markets has been positive in the first year, and then it has been negative for next three years and again positive in the fifth year. According to this study, it seems that how to select the finance institutes, and fame and validity of these institutes affect the price of new stocks and it should be considered in initial public offering of the stocks by the firms in stock exchange.

Banz (1981) was studied the effect of firm size on return and performance of newly accepted firms in Stock Exchange Companies. The stockholders' equity amount in stock exchange has been the criterion of measuring the firm size. The results of this study confirm the higher level of initial return in small firms comparing to big firms in longer terms.

Ritter (1984) identified a hot oil and gas market in the U.S. in 1980. The reason of such a market is imputed to Iran Revolution in 1979, which led to a lot of unreliability in gas and oil prices and increasing the stock price rapidly in the first day of transaction. Ritter has reported the average price return of initial public offering up to the first next price more than $48 \%$ between 1980 and 1981.

Clifford in 1986 has designed a rational model to show the influence of the auditor's fame and quality and also the institute that supports the stock selling and is selected by newly accepted institutes. According to this model, the more famous and qualified the auditor and the related institute are, the more money is paid on behalf of the stockholders to buy the firm 
stock; because more desirable conditions can be observed and more prosperous future can be predicted by stockholders.

Allen and Faulhaber (1989) tested the signaling hypothesis. They claimed that information asymmetry in the market is the reason that firms signal their quality to investors by offering the underpriced stocks and anticipate providing their required capital in a better condition in the future.

Eyssel and Kummer (1993) have been studied signaling phenomenon in market via Leland and Pyle (1977) model in their research. Newly accepted firms in the US stock exchange from 1982 to 1986 were chosen for this test. The results are as follow:

1. The more firm stock offering to internal stockholders, the less short term returns out of stock transactions.

2. In this case, most of the firm stockholders sell their stocks after initial public offering.

3. Internal transactions can be a signaling and effective factor in market about the quality of firm stocks.

Jahankhani and Abdolahzadeh (1993) in an article named "The study of quality of pricing in Tehran Stock Exchange" following suggestions are stated by them:

1. Determining the stock basic price should be granted to professional independent organizations.

2. If there is no professional independent organization, the stock basic price should be determined according to analyzing of related industries and firms, discounting rate on the basis of investing risk, and growth rate of future profits in accordance with increasing the firm profitability.

3. More experts should be employed by TSE for stock evaluation.

Talebi (1995) in his Ph.D. thesis, titled "A Study of Problems in Stock Pricing Methods", the stock price of the first transaction in the firms, which were subjected to privatization, in TSE was compared to the present value of their future earnings in order to discover the probable advantages and disadvantages of the pricing model. According to obtained results in this study, the stock price cannot be determined acceptably on the basis of financial and economical data and decisions have mostly been made according to personal judgments of people in charge and their mental predictions and limited information.

Loughran and Ritter (1995) have tested the trends of stock long term returns at the time of issue in Stock Exchange. Their results represent that between 1970 and 1990, the companies, which were in charge of stock issue, offered less returns during the first 5 years after going public time, comparing to some other companies that had no stock issue.

The results of Ritter study in 1998 confirm the abnormal phenomenon of existing specific periods in stock transaction volume and average initial stock return. Existing of hot issue market hypothesis is confirmed by this study as well. Risk aversion of companies, which are 


\section{Mll Macrothink}

International Journal of Accounting and Financial Reporting ISSN 2162-3082 2013, Vol. 3, No. 1

in charge of stock issue, and firms, which guarantee the sale, is a reason that Ritter refers to as abnormal phenomena in stock market of newly accepted firms. Mentioned firms try to guarantee the sale of their bonds -including stocks- and decrease the risk of selling the bonds in this way.

Howton and Olsen (2001) discussed the relation between the structure of board of directors and short term and long term return in newly accepted firms is discussed in this study. It has claimed that information asymmetry and lack of managers' familiarity to the market environment are the reasons in poor performance of market toward the newly accepted firms. The results show a direct relation between the board of directors' structure and return of stock transaction in newly accepted firms.

The research by Welch and Ritter (2002) is about evaluation of the US stock exchange between 1980 and 2001. Results indicate that at the end of the first day in stock and bonds transaction of newly accepted firms in the exchange market, on average the transaction price is $18.6 \%$ more than its sold price at the beginning of firm stock transaction by the parent firm. Also, it was cleared that after three years, the average pricing and weak evaluation of these firms has been $23.4 \%$ comparing to the market index. According to these two researchers, the quality of subscribers' activities and quality of allocating the stocks of newly accepted firms in Stock Exchange Company have been the reasons of such a phenomenon in stock exchange.

Drobetz et al. (2003) was evaluated the performance of Switzerland stock exchange toward the newly accepted firms. A set of stock exchange data - between 1983 and 2000 - was applied and it was tried to evaluate and test a number of effective factors on efficiency of stock exchange toward the newly accepted firms. This point should be pointed out that the influence of all hypotheses was tested on the main hypothesis one by one and also the joint influence of them according to various declared hypotheses was tested as well in this study. Results show that the average amount of initial adjusted market return equals $34.97 \%$ comparing to the newly accepted firms. Considering all different parts of the market, it can be stated that average return equals $11.32 \%$ in main part and it equals 38.98 in new parts of Switzerland stock exchange. Also, results show that the hypothesis of uncertainty about the return of newly accepted firms, signaling hypothesis, and approximately the hypothesis of existing a specific period in the market can justify the underpricing phenomenon in Switzerland stock exchange.

Abdeh Tabrizi and Demuri (2003) were studied on the firms, whose stocks were transacted in TSE for the first time from 1990 to 1995, and resulted consequences represented that "Transient trends and attitudes" and "Extravagant reaction" hypotheses can be proved for investors in some industries. The results of this study also showed that the behavior pattern of new stock return in TSE is similar to other countries approximately, and the people, who have bought the new stocks at the primary issue in the stock exchange, get more return comparing to the market return, if they sell their stock two months later. And the average rate of accumulative abnormal return of new stocks moves downward in a long term thirty four-month period, in spite of all fluctuations. Furthermore, relative wealth in a long term thirty four-month period moves downward as well, in spite of all fluctuations. 


\section{Ml Macrothink}

International Journal of Accounting and Financial Reporting

ISSN 2162-3082 2013, Vol. 3, No. 1

Nahavandi (2005) have been studied on the short term abnormal return related to the industry, the stock volume, stock ownership level and going public time from 1997 to 2003 at the time of going the firm to TSE.

Maria Borges (2007) was studied in an article titled "Public Offering of Underpriced New Stocks", Portugal market and stock initial public offering in last 20 years. It explains the hot stock market in Portugal in 1987, and also IPO between 1988 and 2004. The article evaluate the underpricing of new stocks in Portugal by studying the behavior of initial return and firm long term performance, it also calculates the returns of market in a 3-year period of time in these firms. 57 samples of initial public offering were evaluated separately for 1987 hot issue market and 41 samples of initial public offering were evaluated for a period of time between 1988 and 2004. The results of research for IPO in 1987 are listed below:

1. Excessive and unique volume of initial public offering leads to strong tax motives.

2. The momentary demanded opportunity for investors (with high volume of promissory notes transactions) is the main reason of centralization on IPO in second half of 1987.

3. Offering underpriced new stocks was about $87.5 \%$ averagely before crumbling of prices in Stock Exchange Company, but no underpricing could be seen after the crumbling of prices.

4. IPO before the crumbling of prices in Stock Exchange Company showed less long term return comparing to IPO after crumbling of prices.

The results of research for IPO between 1988 and 2004 are as follow:

1. Underpricing the stocks equaled $11.1 \%$ averagely.

2. Seasonal IPO shows a positive abnormal return in next 3 years after going public time.

3. No difference was observed between underpricing IPO in governmental and private firms.

4. No influence was observed about the firm size in underpricing of IPO.

\section{Research Methodology}

\subsection{Variables Definition}

Abnormal Return (AR) as a dependant variable in this study can be defined as the difference between the actual return of the stock and the actual market return; it can be measured as follow:

$A R_{s_{i}, t}=R_{s_{i} t}-R_{m_{i} t}$

Where:

$A R_{s, t}$ is the abnormal return of the firm $(s)$ in week $(t)$, 
$R_{s, t}$ is the actual return of the firm $(s)$ in week $(t)$, and

$R_{m, t}$ is the actual market return in week $(t)$.

Offered stock volume as an independent variable means the number of stocks that are exposed to sell until the end of the first week after the IPO. It can be measured as follow:

\section{The number of of fered stock in the 1st week of offering$$
\text { Total number of firm stock during the of fering }
$$

The volume of offered stock $=$

Going Public Time According to Common Market Conditions: The index of each stock exchange represents the capital market conditions and also reflects the economical situations in every country. Decreasing the stock price means economy stagnation and increasing the stock price means economy prosperity. The index of Tehran stock exchange began in 1990 and is known as TEPIX internationally. Total stock price index for determining the going public time in TSE is considered on the basis of prevalent market conditions (independent variable), because mentioned index is measured according to all accepted stocks in TSE, and price of each issued stock is taken into consideration and also the index is measured momentarily.

Stock ownership centralization as an independent variable refers to the quality of stock ownership distribution among the stockholders. In other words, a firm is called centralized if most of the stocks are owned by limited number of stockholders.

Firm Size: There are many viewpoints about the firm size -as an independent variable. These viewpoints regard various indices as the firm size. The most important indices are total assets, total sales, the stock market value and stockholders' equity.

Different viewpoints about the firm size lead to different results. Since the selected firms in this paper are mostly of centralized type, the firm total assets are applied in firm size aspect.

\subsection{Statistical Population and Sampling}

Statistical population of the research includes all newly accepted oil and chemical firms in TSE. And Statistical sampling includes all newly accepted oil and chemical firms in TSE between 2001 and 2012.

During the research, 31 oil and chemical firms were accepted in TSE between 2001 and 2012, and 29 firms were chosen as the research samples on the basis of following conditions:

1) Being accepted in TSE between 2001 and 2012.

2) In a period of 4 weeks after the IPO, their stocks have to be transacted at least in 3 transactional weeks.

3) During the mentioned weeks, no announcements have to be made about the dividend distribution, distribution of script, split up, justifying and predicting the profit and 


\section{Macrothink \\ International Journal of Accounting and Financial Reporting

holding a general meeting.

4) The required data of the firm have to be available.

\subsection{Research Hypotheses}

Main Hypothesis:

$\mathbf{H}_{\mathbf{0}}$ : There is no abnormal return from IPOs of oil and chemical firms in TSE.

Secondary Hypotheses:

$\mathbf{H}_{01}$ : There is no meaningful relation between stock offering volume and abnormal return of IPO price in oil and chemical firms.

$\mathbf{H}_{\mathbf{0 2}}$ : There is no meaningful relation between going public time according to usual market conditions and abnormal return of IPO price in oil and chemical firms.

$\mathbf{H}_{\mathbf{0 3}}$ : There is no meaningful relation between stock ownership centralization and abnormal return of IPO price in oil and chemical firms.

$\mathbf{H}_{\mathbf{0 4}}$ : There is no meaningful relation between the firm size and abnormal return of IPO price in oil and chemical firms.

\subsection{Testing the Research Hypotheses method}

Considering the special conditions in Iran, four secondary hypotheses were discussed in this paper for short term return of newly accepted oil and chemical firms comparing to other firms. Provided that the primary hypothesis is confirmed, its effect on this phenomenon will be evaluated once as a Single Hypothesis Test and again as a Joint Hypothesis Tests. A 4-week period is chosen in this study to measure the selected performance, and all changes of newly accepted stock prices in these 4 weeks are applied as pricing criterion. Short term return of newly accepted stocks is compared with short term return of the market in this period.

For testing the main hypothesis, the difference between the short term return of newly accepted firms and the short term return of the market is calculated and the main hypothesis is tested by the numerical amount of zero statistically. Provided that the difference equals zero or a negative amount, the main hypothesis will be rejected; otherwise the main hypothesis of the research is confirmed. This hypothesis explanation can be defined statistically as follow:

$H_{0}=A R \leq 0$

$H_{1}=A R>0$

T-test is applied for testing the main hypothesis.

A regression equation is applied to test the first secondary hypothesis as below: 


\section{I Macrothink}

$A R_{\mathrm{i}}=C+\beta X_{\mathrm{i}}+\mathrm{E}$

Where, $A R_{\tilde{i}}$ is the difference of firm stock price changes according to the short term market changes, $C$ is a constant in the regression equation, $\beta$ is the explanatory variable coefficient, $X_{\tilde{\mathrm{I}}}$ is the explanatory independent variable - the percentage of offered stocks - and $\mathcal{E}_{\text {is }}$ the error term in regression model.

Also, the One-Way ANOVA method is applied to test the second, third and fourth hypotheses separately. The effects of all variables are tested one by one on the dependant variable in this model as below:

$A R_{i, t}=\mu+\omega_{i}+\epsilon$

Where, ${ }^{A R_{\mathrm{i}, \mathrm{t}}}$ is the difference of new stock price according to the short term market changes,

$\mu$ is the constant effect of model, $\omega_{i}$ is the effect of considered factor variable in the secondary hypothesis that can be the stock ownership centralization, going public time and firm size, and ${ }^{E}$ is the random error in variance analyze model.

Joint effect of independent variables, which are discussed in the secondary hypotheses, is tested on the dependant variable -abnormal return- by multivariate variance analyze model after testing all hypotheses one by one by mentioned equations. According to this method, three factor variables and a concomitant variable are tested on the response (or dependant) variable in this case as follow:

$A R_{i j k}=\mu+\beta\left(X_{i j k}-\bar{X}\right)+\tau_{i}+v_{j}+\delta_{k}+\epsilon$

Where, ${ }^{A R_{i j k}}$ is the difference of new stock price changes according to the short term market changes, ${ }^{\mu}$ is the public effect of factor variables, ${ }^{\beta}$ is the concomitant variable coefficient that here is the same as the percentage of stock offering, $X_{i j k}$ is the explanatory concomitant variable for measuring the effect of stock offering percentage in the first firm transaction in TSE, $\bar{X}$ is the average amount of the concomitant variable, $\tau_{\tilde{i}}$ is the effect of factor variable of going public time of the newly accepted firm in TSE, $v_{j}$ is the effect of factor variable of stock ownership centralization, ${ }^{\delta_{k}}$ is the effect of factor variable of newly accepted firm size, 
and $E$ is the error term in the residual of the equation.

\section{Results of Testing the Research Hypotheses}

\subsection{Results of testing the main hypothesis}

As it can be seen in table 1 , the results of testing the main hypothesis reject the $\mathrm{H}_{0}$ and confirm the $\mathrm{H}_{1}$. Considering the significance level of 0.005 , it can be observed that the number is less than Alfa (0.05) according to the table.

Table1: The results of testing the main hypothesis

\begin{tabular}{|l|l|l|l|l|}
\hline $\begin{array}{l}\text { The Main } \\
\text { Hypothesis }\end{array}$ & $\begin{array}{l}\text { Degree } \\
\text { freedom }\end{array}$ & $\begin{array}{l}\text { Significance } \\
\text { level }\end{array}$ & $\begin{array}{l}\text { Lower bounds of } \\
\text { confidence interval }\end{array}$ & $\begin{array}{l}\text { Upper bounds of } \\
\text { confidence interval }\end{array}$ \\
\hline Abnormal Return & 28 & 0.005 & 0.0386 & 0.1972 \\
\hline
\end{tabular}

Furthermore, since both obtained bounds of confidence interval from the statistical test are positive, i.e. 0.1972 and 0.0368 , it can be claimed that short term stock return from buy and sale of newly accepted oil and chemical firms is more than short term return of other firms at the same period of time. Fig. 1 depicts this point in accordance with the results of testing the hypothesis.

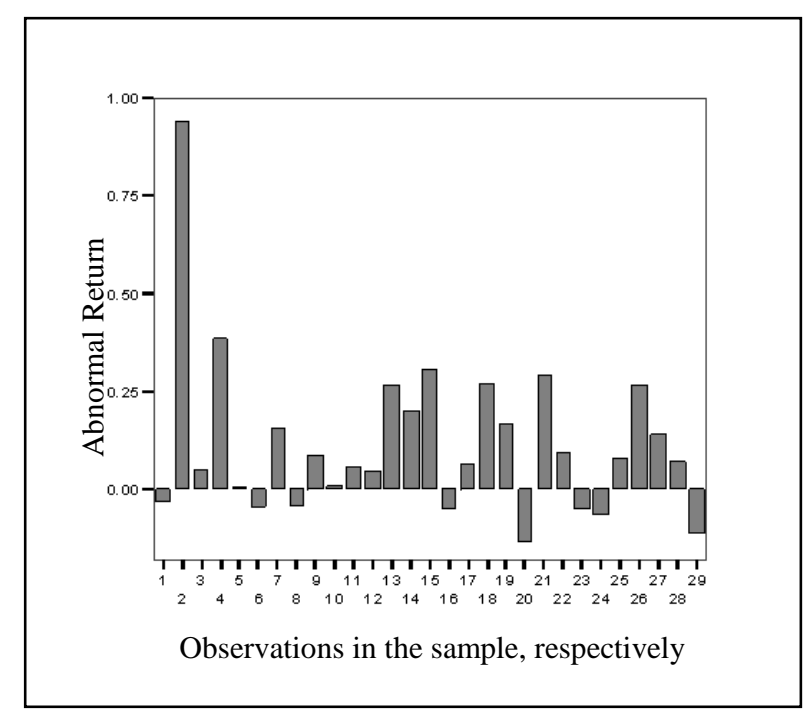

Fig.1: Actual return of newly accepted oil and chemical firms comparing to the market return at the same period of time

Statistical explanation of the first secondary hypothesis (offered stock volume) is as below:

$$
H_{0}: \rho=0
$$

$H_{1}: \rho \neq 0$ 


\section{Mll Macrothink}

International Journal of Accounting and Financial Reporting ISSN 2162-3082

Where, $\rho$ is the correlation coefficient of offered stocks percentage and abnormal return between the newly accepted oil and chemical firms and other firms return. To test this hypothesis, at first the linear correlation between the independent variable of stock offering percentage and dependant variable of abnormal return is tested via the correlation test in order to be certain about the existence of a linear relation between these two variables. According to table 2, the result of testing shows no linear relation between the independent variable of stock offering at the first going public time and dependant variable of abnormal short term return. The significance level and obtained Pearson correlation coefficient between the variable of abnormal short term return and variable of stock offering amount in correlation coefficient table confirms this point as well.

Table 2: Correlation coefficient table between stock offering percentage and abnormal return

\begin{tabular}{|l|l|l|l|l|}
\hline Variable & $\begin{array}{l}\text { Pearson coefficient } \\
\text { AR (beta coefficient) }\end{array}$ & $\begin{array}{l}\text { AR } \\
\text { significance } \\
\text { level }\end{array}$ & $\begin{array}{l}\text { F-Test } \\
\text { (Fischer Distribution) }\end{array}$ & $\begin{array}{l}\text { Determination } \\
\text { coefficient }\end{array}$ \\
\hline $\begin{array}{l}\text { Stock Offering } \\
\text { Percentage }\end{array}$ & -0.252 & 0.204 & 1.702 & 0.064 \\
\hline
\end{tabular}

Also, existing of a probable non-linear relationship between these two variables can be studied by a scatter diagram. Fig. 2 shows the scatter diagram for probability of a non-linear relation between the variable of abnormal short term return and variable of stock offering percentage by newly accepted firms at their first transaction. According to scatter diagram in fig.2, no clear trend can be seen to show a non-linear relation between two variables. This point can be confirmed by the fitting direct line on the obtained information.

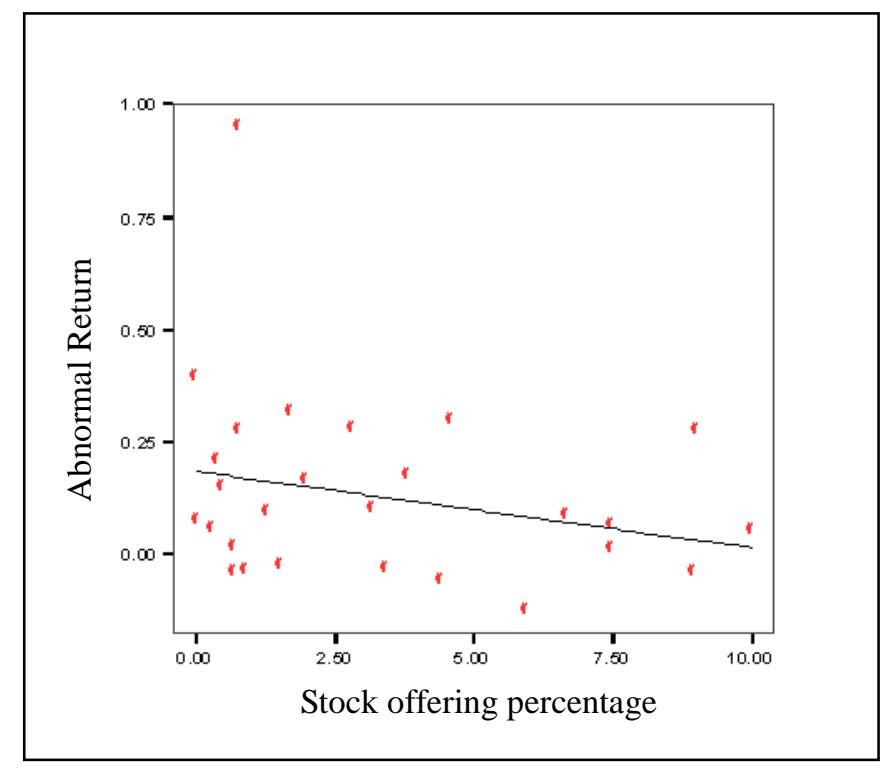

Fig.2: Variance chart between the independent variable of stock offering percentage and dependant variable of abnormal return 


\section{Macrothink}

International Journal of Accounting and Financial Reporting

Statistical explanation of the $2^{\text {nd }}$ secondary hypothesis (going public time) is as below:

$H_{0}: \tau_{1}=\tau_{2}$

$H_{1}: \tau_{1} \neq \tau_{2}$

Where, ${ }^{\tau}$ is the going public time for newly accepted oil and chemical firms (during the market stagnation). It should be pointed out that following cases need to be evaluated in order to test the second, third and fourth hypotheses:

1. Leven test (Variances equality)

2. Normality test of residual (Kolmogorov-Smirnov test)

3. Residual independence hypothesis (Durbin-Watson test)

Considering this point that significance level of the independent variable of going public time (0.003) is less than 0.05 in Leven test, the variance equality hypothesis is rejected, so according to the second line of table 2 (testing the variance equality), the significance level increases to 0.529. About testing the normality of residual, considering this point that significance level of going public time variable $(0.13)$ is more than 0.05 , so the normality of residual is still in existence. Since the obtained number from Durbin-Watson test about the independence of residual equals 2.381 and this number is close to 2, so the hypothesis of the residual is confirmed. As it can be seen in table 3, the independent factor variable of going public time of oil and chemical firms does not affect the dependant variable of abnormal return. It means that there is no meaningful difference statistically in the abnormal short term return of newly accepted oil and chemical firms either in the market prosperity or in stagnancy. This point can be confirmed by significance level of 0.210 that is resulted from mentioned test.

Table 3: Variance analysis of independent factor variable of going public time

\begin{tabular}{|l|l|l|l|l|}
\hline Tested Variable & $\begin{array}{l}\text { Freedom } \\
\text { degree }\end{array}$ & F-Test & $\begin{array}{l}\text { Significance } \\
\text { level }\end{array}$ & $\begin{array}{l}\text { Determination } \\
\text { coefficient }\end{array}$ \\
\hline Going Public Time & 1 & 1.647 & 0.210 & 0.058 \\
\hline
\end{tabular}

Fig. 3 depicts the effect of two variables in different periods of time according to the bar graph. As it can be seen in this fig. 3, considering this point that the average amount of abnormal return from the transactions of newly accepted oil and chemical firms classified in two different classes, i.e. prosperous and stagnant markets, as bar graphs in one row, lack of any difference in factor variable of going public time can be seen, which confirms the results of a secondary hypothesis (going public time) on the basis of variance analysis statistical method. 


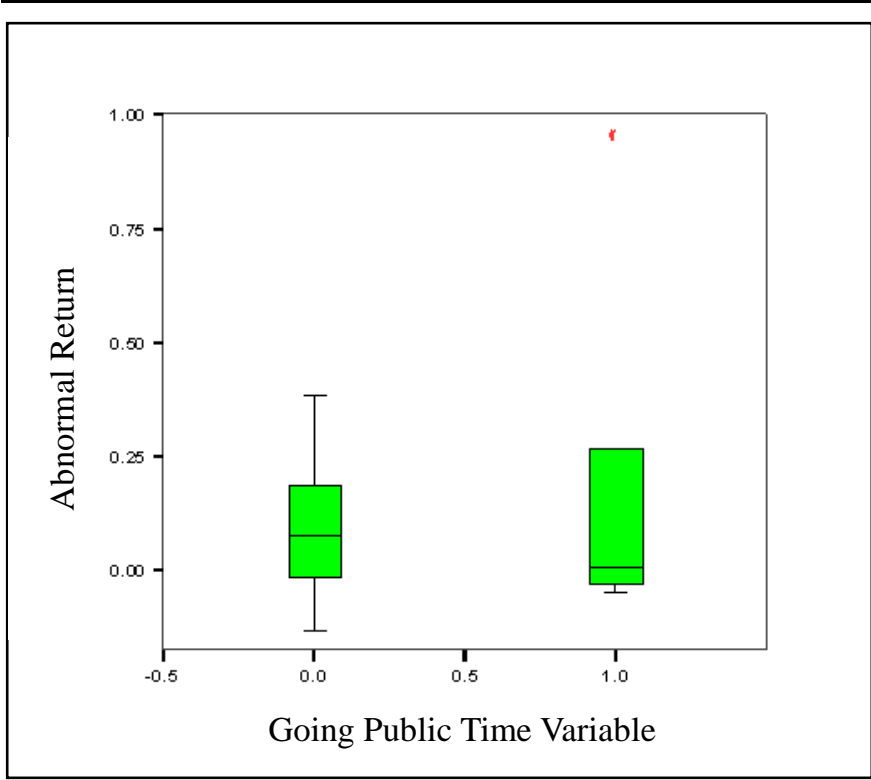

\section{Fig.3: Bar graph of abnormal return in different periods of the year}

Statistical explanation of the third secondary hypothesis (stock ownership centralization) is as below:

$H_{0}: v_{1}=v_{2}$

$H_{1}: v_{1} \neq v_{2}$

Where, ${ }^{v}$ is the effect of factor variable of stock ownership centralization in newly accepted oil and chemical firms by natural and legal person (stockholders who own more than 50\% and less than 50\%). Considering this fact that significance level that is related to normality of residual (0.12) and variance equality $(0.344)$ are more than 0.05 , so both discussed hypotheses are confirmed. Also, since Durbin-Watson statistic in variable of stock ownership centralization (2.289) is close to 2, the residual independence hypothesis is confirmed as well. Results from testing this hypothesis, which were obtained via variance analysis test, show that according to table 4 factor variable of stock ownership centralization does not affect the dependant variable of abnormal return of newly accepted oil and chemical firms. Because significance level of 0.61 is more than the chosen Alfa (0.05).

Table 4: Variance analysis of factor variable of stock ownership centralization

\begin{tabular}{|l|l|l|l|l|}
\hline Tested Variable & Freedom degree & F-Test & $\begin{array}{l}\text { Significance } \\
\text { level }\end{array}$ & $\begin{array}{l}\text { Determination } \\
\text { coefficient }\end{array}$ \\
\hline $\begin{array}{l}\text { Stock Ownership } \\
\text { Centralization }\end{array}$ & 1 & 0.266 & 0.61 & 0.01 \\
\hline
\end{tabular}




\section{Macrothink}

International Journal of Accounting and Financial Reporting

ISSN 2162-3082 2013, Vol. 3, No. 1

The bar graph in fig. 4 depicts the lack of the variable effect on abnormal return. Since the average of abnormal return in newly accepted oil and chemical firms that is classified in two different classes, i.e. stockholders who own more than $50 \%$ and less than $50 \%$, are located in one row, lack of any difference in factor variable of stock ownership centralization can be seen, which confirms the results of this secondary hypothesis (stock ownership centralization) on the basis of variance analysis statistical method.

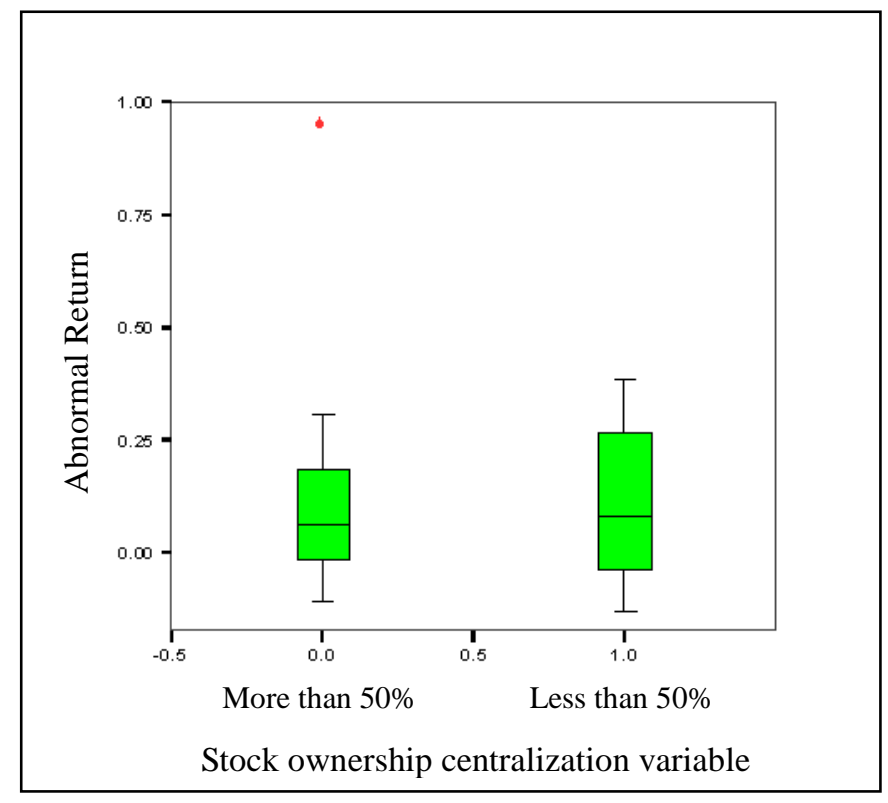

\section{Fig.4: Bar graph of abnormal return in different stock ownership centralization}

Statistical explanation of the fourth secondary hypothesis (size of newly accepted oil and chemical firms) is as below:

$H_{0}: \delta_{1}=\delta_{2}$

$H_{1}: \delta_{1} \neq \delta_{2}$

Where, ${ }^{\delta}$ is the size of newly accepted firm that is classified into two different classes; i.e. big and small firms. Considering this fact that significance level that is related to normality of residual (0.61) and variance equality number (0.096) are more than 0.05 , so both discussed hypotheses are confirmed. Also, since the residual independence hypothesis (2.199) is close to 2 , the residual independence hypothesis is confirmed as well. Results from testing this hypothesis, which were obtained via variance analysis test, show that according to table 5 factor variable of firm size affects the dependant variable of abnormal return of newly accepted oil and chemical firms. Because significance level of 0.032 is less than the chosen Alfa amount (0.05). According to obtained statistical results, big firms have more abnormal return than small firms. 


\section{Mll Macrothink \\ International Journal of Accounting and Financial Reporting \\ ISSN 2162-3082 2013, Vol. 3, No. 1}

Table 5: Variance analysis of factor variable of firm size

\begin{tabular}{|l|l|l|l|l|}
\hline $\begin{array}{l}\text { Tested } \\
\text { Variable }\end{array}$ & $\begin{array}{l}\text { Freedom } \\
\text { degree }\end{array}$ & F-Test & Significance level & Determination coefficient \\
\hline Firm Size & 1 & 5.099 & 0.032 & 0.159 \\
\hline
\end{tabular}

Since the average of abnormal return in newly accepted oil and chemical firms that is classified in two different classes, i.e. big and small firms, are not located in one row in bar graph, fig. 5, so the difference between two levels in factor variable of firm size can be seen, which confirms the results of this secondary hypothesis (firm size) on the basis of variance analysis statistical method.

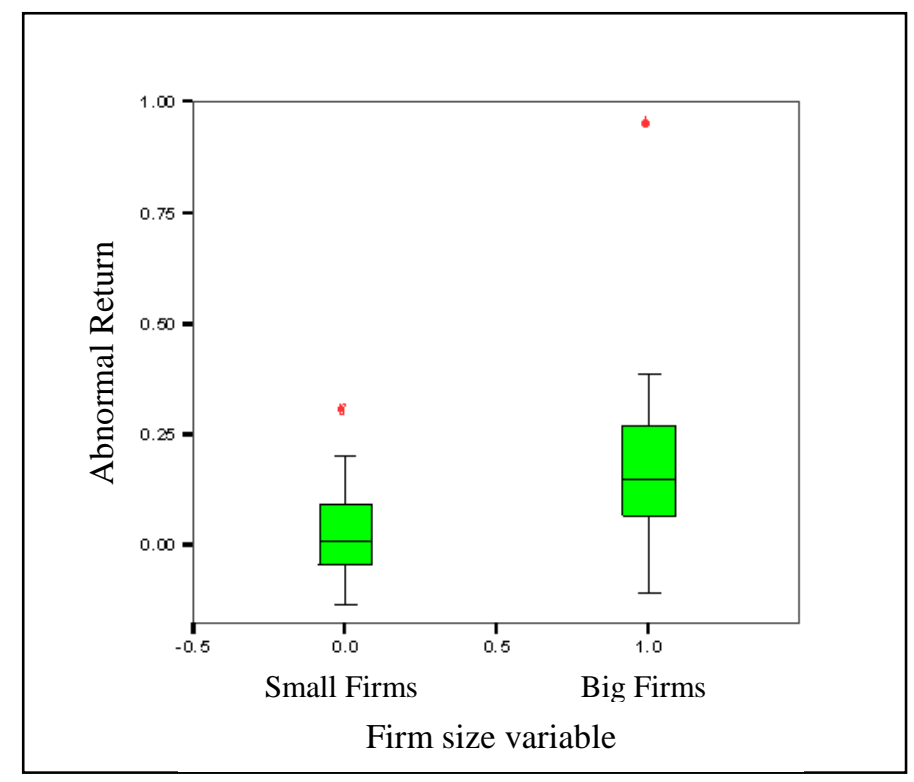

\section{Fig.5: Bar graph of abnormal return in firms with different sizes}

\subsection{Results of joint testing of the research secondary hypotheses}

In order to fulfill this test, three variables of going public time of the newly accepted firm, stock ownership centralization and firm size are considered as factor variables and stock offering percentage is considered as an concomitant variable. Variance analysis method is applied in several factors to fulfill the joint test in mentioned variables. The results of this test and the main joint effect of secondary hypotheses are represented in table 6 . 


\section{Ml Macrothink}

International Journal of Accounting and Financial Reporting

Table 6: Results of Joint test in discussed variables of secondary hypotheses

\begin{tabular}{|l|l|l|l|}
\hline Tested Variable & F-Test & Significance level & Freedom degree \\
\hline Stock Offering Percentage & 0.694 & 0.414 & 1 \\
\hline Going Public Time & 0.090 & 0.767 & 1 \\
\hline Stock Ownership Centralization & 0.594 & 0.450 & 1 \\
\hline Firm Size & 6.921 & 0.016 & 1 \\
\hline
\end{tabular}

This table clarifies that considering the joint effect of secondary hypotheses in the research, none of the variables affect the abnormal return of newly accepted oil and chemical firms, except for the firm size, which is 0.016 meaningful. According to table 5 , the factor variable of the firm size affects the abnormal return of newly accepted oil and chemical firms separately (significance $=0.032$ ). Then, the significance test of regression equations for variables coefficients was fulfilled. Results showed that among all mentioned variables, the size of newly accepted oil and chemical firms was the only variable that affects the abnormal return of initial public offering meaningfully. Thus, the backward method is applied to exclude the meaningless variables and fit the final regression. Result of the final fitting is shown in table 7 .

Table 7: Results of backward test in joint considering of the variables

\begin{tabular}{|c|c|c|c|}
\hline Model & Independent Variable & Significance level & $\mathrm{t}$-Statistic \\
\hline 1 & Going Public Time & 0.269 & 1.129 \\
\hline 2 & $\begin{array}{l}\text { Going Public Time } \\
\text { Offered Stock Volume }\end{array}$ & $\begin{array}{l}0.403 \\
0.406\end{array}$ & $\begin{array}{l}0.851 \\
-0.845\end{array}$ \\
\hline 3 & $\begin{array}{l}\text { Going Public Time } \\
\text { Offered Stock Volume } \\
\text { Stock Ownership Centralization degree }\end{array}$ & $\begin{array}{l}0.437 \\
0.419 \\
1.00\end{array}$ & $\begin{array}{l}0.790 \\
-0.822 \\
0.00\end{array}$ \\
\hline
\end{tabular}

According to table 7, first the variable of going public time is excluded from the model, and then offered stock volume, and finally that variable of stock ownership centralization. As it can be seen in the table, firm size is the only remained variable in backward method. 


\section{Conclusion}

Results of all different tests, which were discussed in this research, are summarized in table 8.

Table 8: Summary of testing all different hypotheses in this research

\begin{tabular}{|c|c|c|c|}
\hline & Null hypotheses & Test Type & $\begin{array}{l}\text { Test of null } \\
\text { hypothesis } \\
\text { Results }\end{array}$ \\
\hline $\begin{array}{l}\text { Main } \\
\text { Hypothesis }\end{array}$ & $\begin{array}{l}\text { There is no abnormal return from } \\
\text { IPO of oil and chemical firms in } \\
\text { TSE. }\end{array}$ & t-statistic & Reject \\
\hline $\begin{array}{l}1^{\text {st }} \text { secondary } \\
\text { Hypothesis }\end{array}$ & $\begin{array}{l}\text { There is no meaningful relation } \\
\text { between stock offering volume and } \\
\text { abnormal return of IPO price in oil } \\
\text { and chemical firms. }\end{array}$ & Regression & Accept \\
\hline $\begin{array}{l}2^{\text {nd }} \text { secondary } \\
\text { Hypothesis }\end{array}$ & $\begin{array}{l}\text { There is no meaningful relation } \\
\text { between going public time according } \\
\text { to usual market conditions and } \\
\text { abnormal return of IPO price in oil } \\
\text { and chemical firms. }\end{array}$ & $\begin{array}{l}\text { Variance } \\
\text { analysis }\end{array}$ & Accept \\
\hline $\begin{array}{l}3^{\text {rd }} \text { secondary } \\
\text { Hypothesis }\end{array}$ & $\begin{array}{l}\text { There is no meaningful relation } \\
\text { between stock ownership } \\
\text { centralization and abnormal return } \\
\text { of IPO price in oil and chemical } \\
\text { firms. }\end{array}$ & $\begin{array}{l}\text { Variance } \\
\text { analysis }\end{array}$ & Accept \\
\hline $\begin{array}{l}4^{\text {th }} \text { secondary } \\
\text { Hypothesis }\end{array}$ & $\begin{array}{l}\text { There is no meaningful relation } \\
\text { between the firm size and abnormal } \\
\text { return of IPO price in oil and } \\
\text { chemical firms. }\end{array}$ & $\begin{array}{l}\text { Variance } \\
\text { analysis }\end{array}$ & Reject \\
\hline
\end{tabular}

From the above table can claim that there is a positive abnormal return to investing in the newly accepted oil and chemical firms for stockholders in Tehran Stock Exchange (TSE). It also concludes that the firm size is the only factor can affect the stock abnormal return. With considering significance level, investors have to give attention sequentially to other variables such as stock ownership centralization, going public time and stock offering volume. 


\section{Macrothink}

International Journal of Accounting and Financial Reporting ISSN 2162-3082 2013, Vol. 3, No. 1

\section{References}

Abdeh Tabrizi, Hossein and Demury, Dariush (2003). "Identifying the Effective Factors in Stock Return of Newly Accepted Firms in Tehran Stock Exchange". Financial Researches Quarterly Periodical, year 5, no 15, p 24, Management Department Publications, Tehran University.

Allen and Faulhaber (1989). "Signaling by Underpricing in the IPO Market", Journal of Financial Economics, pp. 303-323.

Banz (1981). "The Relationship Between Return and Market Value of Common Stocks", Journal of Financial Economics, no.9, pp.3-18.

Clifford (1986). "Investment Banking and the Capital Acquisition Process", Journal of Financial Economics, No. 15, pp. 3-29.

Drobetz, Kammerman and Walchli (2003). "Performance of Initial Public Offering: The Evidence for Switzerland", Working paper, Basel University.

Eyssel and Kummer (1993). "Signaling, Insider Trading and Post Offering Performance", Journal of Applied Business Research, No. 9, pp. 80-93.

Geranmayeh, Sirous, "Investing M.S.", Boursnegar Analyzing Group, August 2 ${ }^{\text {nd }}, 2006$.

Haqjoo, Nasser, "Capital" Newspaper, August 27 $7^{\text {th }}, 2006$.

Howton and Olsen (2001). "Board Ownership and IPO Returns", Journal of Economics and Finance, No. 25,pp. 100-115.

Ibbotson (1975). "Price Performance of Common Stock New Issues", Journal of Financial Economics, No. 2, pp. 235-272.

Jahankhani, Ali and Abdollahzadeh, Farhad (1993), "Quality of Pricing in Tehran Stock Exchange". Financial Researches" Quarterly Periodical, year 1, no 1, pp 76, 77, Management Department Publications, Tehran University.

Leland and Pyle (1977). "Information Asymmetries, Financial Structure and Financial Intermediation", Journal of Finance, Vol. 32, No. 2, pp. 371-387.

Loughran and Ritter (1995). "The New Issues Puzzle, Journal of Finance, No. 50, pp. 23-51.

Maria Rosa Borges (2007)." Underpricing of Initial Public Offering The Case of Portugal", International Atlantic Economic Society 2007, www.springer.com.

Nahavandi, Ehsan (2005), "Evaluating the Stock Price in Initial Public Offering". M.S. Thesis, Azad Islamic University, Mashhad.

Ritter (1984). "The Hot Issue Market of 1980", Journal of Business, No. 57, pp. 215-240.

Ritter (1998). "Initial Public Offering", Journal of Contemporary Finance Digest, Vol. 2, pp. $5-30$. 


\section{Macrothink}

International Journal of Accounting and Financial Reporting ISSN 2162-3082

Welch and Ritter (2002). "A Review of IPO Activity, Pricing and Allocation", Working paper, Yale University.

Yari, Sorayya and Forqandoust Haqiqi, Kambiz (2003), "A New Method to Determine the Stock Price". Bourse Monthly Periodical, no 34, p 42. 